\title{
Seed priming and sulfur effects on soybean cell membrane stability and yield in saline soil
}

\author{
Teymur Khandan Bejandi(1), Mohammad Sedghi(2), Raouf Seyed Sharifi(2), Ali Namvar ${ }^{(1)}$ and Peyman Molaei(1) \\ (1)Islamic Azad University, Young Researchers Club, Ardabil Branch, Iran. E-mail: khandan_62@yahoo.com, namvar_a60@yahoo.com, \\ molaei_p59@yahoo.com (2)University of Mohaghegh Ardabili, Faculty of Agronomy and Plant Breeding, College of Agriculture, Ardabil, Iran. \\ E-mail: mosedghi2003@yahoo.com,raouf_ssharifi@yahoo.com
}

\begin{abstract}
The objective of this work was to determine the effects of seed priming and sulfur application on cell membrane characteristics, seedling emergence, chlorophyll content and grain yield of soybean (Glycine max) in saline soil. A complete-block design in $4 \times 3$ factorial arrangement with three replicates was used to test four types of seed priming (water, auxin, gibberellin and non-priming) and three levels of sulfate availability ( 0 , 70 and $140 \mathrm{~kg} \mathrm{ha}^{-1} \mathrm{~K}_{2} \mathrm{SO}_{4}$ ). The soil had a silty loam texture with an electrical conductivity of $3.61 \mathrm{ds} \mathrm{m}^{-1}$, a $\mathrm{pH}$ of 8.2 and a saturation percentage of about $46 \%$. Seed priming had significant effects on mean emergence rate (MER), emergence percentage, relative water content (RWC) of leaves, relative chlorophyll content, time of maturity, shoot length and grain yield. The highest values for these variables were observed in the priming treatments, except for the time of maturity. Sulfur application had significant effects on MER, shoot length, RWC, membrane injury index and grain yield. Priming treatments provide greater emergence rates and grain yields and interact sinergicaly with sulfur rates.

Index terms: Glycine max, chlorophyll content, environmental stress, injury index, seedling emergence.

\section{Condicionamento osmótico das sementes e disponibilidade de enxofre na estabilidade da membrana celular e produtividade de soja em solo salino}

\begin{abstract}
Resumo - O objetivo deste trabalho foi determinar os efeitos do condicionamento osmótico das sementes e da disponibilidade de enxofre sobre características da membrana celular, emergência de plântulas, conteúdo relativo de clorofila e produtividade de soja (Glycine max) em solo salino. O experimento foi conduzido em delineamento de blocos ao acaso, em arranjo fatorial $4 \times 3$, com três repetições, para avaliar quatro tipos de condicionamento osmótico das sementes (água, auxina, giberelina e ausência de condicionamento) e três níveis de disponibilidade de enxofre para as plantas (aplicação ao solo de 0,70 e $140 \mathrm{~kg} \mathrm{ha}^{-1}$ de $\mathrm{K}_{2} \mathrm{SO}_{4}$ ). O solo utilizado apresentava textura média, com condutividade elétrica de aproximadamente $3,61 \mathrm{ds} \mathrm{m}^{-1}, \mathrm{pH}$ de $8,2 \mathrm{e}$ percentagem de saturação em torno de $46 \%$. O condicionamento osmótico das sementes teve efeito significativo sobre a taxa média de emergência (MER), percentagem de emergência, conteúdo relativo de água das folhas (RWC), conteúdo relativo de clorofila, época de maturação, comprimento da parte aérea e produtividade de grãos. Os maiores valores para essas variáveis, exceto época de maturação, foram observados nos tratamentos com condicionamento osmótico. A aplicação de enxofre teve efeito significativo sobre MER, comprimento da parte aérea, RWC, índice de dano à membrana celular, e produtividade de grãos. O condicionamento osmótico proporciona maiores taxas de emergência e produtividade de grãos e interage significativamente com a aplicação de enxofre.
\end{abstract}

Termos para indexação: Glycine max, conteúdo de clorofila, estresse ambiental, índice de dano, emergência de plântulas.

\section{Introduction}

A major impact of environmental stress on plants is cellular membrane modification due to salt stress, expressed in increased permeability and leakage of ions. Consequently, the relative water content (RWC) in the leaves decreases with increasing concentrations of salt solution (Kocheva \& Georgiev, 2003). The accumulation of active oxygen species under stress conditions may damage many cell compounds, such as lipids, proteins, carbohydrates and nucleic acids (Bewley \& Black, 1994), and deplete the chlorophyll pool (McDonald, 2000) as a result of cell-membrane lipids peroxidation (Soeda et al., 2005).

Germination and emergence rates are important factors for the successful establishment of crops. Harris et al. (2001) demonstrated that on-farm seed priming (overnight seed soaking, surface drying and sowing) 
markedly improved establishment and early vigor of upland rice, maize and chickpea, resulting in faster development, earlier flowering and maturity and higher yields. This simple, low-cost and low-risk intervention also has positive impacts on extensive farming systems and their economy (Harris et al, 2001).

Sulfur has an essential role in the synthesis of proteins and of a wide variety of metabolites that are critical for plant growth (Ali et al., 1990). Sulfur availability is partially related to soil moisture (Itanna, 2005). Sardans et al. $(2006,2008)$ reported a negative correlation between leaf sclerophylly and leaf $\mathrm{S}$ concentration in a Mediterranean forest. The amino acid profile of soybean meals could be improved with greater amounts of S-containing amino acids, methionine and cysteine. Increasing the amount of these amino acids in soybean meals would enhance their market value (McVey et al., 1995). Sulfur is predominantly absorbed from the soil solution as sulfate anion $\left(\mathrm{SO}_{4}{ }^{2-}\right)$ by plants and transported to chloroplasts in expanding leaves, where most $\mathrm{S}$ reduction is reported to occur (Anderson, 1990).

The objectives of this study were to determine the effects of different seed primings and of sulfur fertilization on soybean cell membrane characteristics, emergence rate, chlorophyll content and grain yield.

\section{Materials and Methods}

The field experiment was done in Ardabil $\left(38^{\circ} 15^{\prime \prime} \mathrm{N}\right.$; $48^{\circ} 15^{\prime \prime} \mathrm{E}$; altitude of $1,350 \mathrm{~m}$ ), northwest Iran, at a research site of University of Mohaghegh Ardabili, in 2007. The experimental area is located in the country's semiarid temperate zone, which features cold winters and moderate summers. The average annual rainfall is about $400 \mathrm{~mm}$, and most rainfall is concentrated between winter and spring (January to June). The soil used was an Entisoil with silty loam texture, with an electrical conductivity (EC) of $3.61 \mathrm{ds} \mathrm{m}^{-1}$, a $\mathrm{pH}$ of 8.20 and a saturation percentage (SP) of about $46 \%$.

The experimental design was of randomized complete blocks in a $3 \times 4$ factorial arrangement with three replicates. The treatments were: $\mathrm{K}_{2} \mathrm{SO}_{4}$ fertilizer rates at 0,70 and $140 \mathrm{~kg} \mathrm{ha}^{-1}\left(\mathrm{~S}_{1}, \mathrm{~S}_{2}\right.$ and $\mathrm{S}_{3}$ respectively), seed priming using distilled water, auxin and gibberellin as pre-sowing treatments, and a control treatment without priming.

Soybean seeds (cv. Williams, maturity group III) were washed with distilled water, dipped in $0.1 \%$ mercuric chloride for $5 \mathrm{~min}$ and then washed thoroughly with distilled water. The washed seeds were divided into four lots: two were fully immersed in aerated auxin and gibberellin solutions (auxin and gibberellin-primed); the third was immersed in aerated water $(1: 2 \mathrm{w} / \mathrm{v})$ (water-primed); and the fourth served as control non-primed seeds. Seeds in pre-sowing treatments were kept in an incubator for $12 \mathrm{~h}$ at $25 \pm 1^{\circ} \mathrm{C}$. The seeds were then washed with distilled water and dried on filter papers at room temperature $\left(25^{\circ} \mathrm{C}\right)$. Seeds were sown in May 2007. Each plot had five $3.2 \mathrm{~m}$ rows with a $40 \mathrm{~cm}$ space between rows and 5 seeds $\mathrm{m}^{-1}$. Potassium sulfate was applied before sowing, at a depth of $8 \mathrm{~cm}$ and a distance of $5 \mathrm{~cm}$ from the seeds. Data from border rows were not taken.

The parameters determined were: shoot length $(\mathrm{cm})$, emergence $(\%)$, mean emergence rate (MER, emerged seedlings per day), time of maturity (days), grain yield $\left(\mathrm{kg} \mathrm{ha}^{-1}\right)$, leaves relative water content (RWC), membrane cell injury index (\%) and relative chlorophyll content (SPAD index).

Relative water content was estimated according to Turner (1981): RWC $=(F W-D W) /(T W-D W)$, where FW is the fresh weight of the leaves; TW is the weight at full turgor, measured after floating the leaves for 24 hours in water under light and at room temperature; and DW is the estimated weight of leaves after drying until constant weight, at $75 \pm 5^{\circ} \mathrm{C}$.

Leaf cell membrane stability (CMS) was measured by polyethylene glycol (PEG) test according to Premachandra (1992). Leaf samples (2 g) were taken at the second leaf stage and immersed in 30\% PEG 6000 (Kimya Garan Co., Tehran, Iran) for 24 hours. For non-desiccated control, the leaf segments were immersed in equal volume of distilled $\mathrm{H}_{2} \mathrm{O}$. After washing with distilled water, the leaf segments were submerged in $30 \mathrm{~mL}$ deionized water for 24 hours. Solution conductivities were measured and the samples were autoclaved for $15 \mathrm{~min}$, cooled to room temperature and then measured once more. The electrolyte leakage was measured using a conductimeter. The CMS and injury index of the samples were calculated according to the equations: $\mathrm{CMS}(\%)=1-(1-\mathrm{T} 1 / \mathrm{T} 2) /(1-\mathrm{C} 1 / \mathrm{C} 2) \times$ 100 and injury index $(\%)=(100-\mathrm{CMS})$, where T1 and $\mathrm{T} 2$ are the first and second conductivity measurements of the desiccated treatment after autoclaving, C1 and $\mathrm{C} 2$ represent the first and second conductivity measurements of the control after autoclaving. Leaves relative chlorophyll content was measured with a 
portable chlorophyll meter (SPAD-502, Minolta, Japan). Daily emergence counts for seedlings that were visible above the soil level with a minimum height of $1.0 \mathrm{~cm}$ were taken for 28 days. The mean emergence rate (MER) was estimated according to Wang et al. (2003): MER $=\frac{\sum \mathrm{n}}{\sum \mathrm{Dn}}$, where $\mathrm{n}$ is the number of emerged seedlings, and D is the sampling day.

Analysis of variance was performed using SAS software package (SAS Institute, 1998) after normality test. The main effects and interactions were tested using Duncan's multiple range test at 5\% probability.

\section{Results and Discussion}

Interaction between treatments was observed in emergence rate and grain yield (Table 1). The highest emergence rate was achieved in $\mathrm{S}_{3}$ with auxin and gibberellin priming, and the lowest was achieved in non-primed treatments and in $\mathrm{S}_{3}$ water priming. Research evidence has indicated that priming soybean seeds before sowing, particularly in low-vigor seeds, improves germination (Wartidiningsih et al., 1994). Priming has been developed and used extensively to improve seed germination and seedling emergence in a wide range of crop species (McDonald, 2000).

Grain yield increased with sulfur $\left(\mathrm{S}_{2}\right.$ and $\left.\mathrm{S}_{3}\right)$ and priming (water, auxin and gibberellin) treatments in comparison with control plots ( $\mathrm{S}_{1}$ and non-priming). The highest grain yield was observed in the interaction between $\mathrm{S}_{2}$ and $\mathrm{S}_{3}$ with auxin, gibberellin and water priming respectively. The lowest grain yield was achieved at $S_{1}$ with non-priming (Table 1). Similar results were reported for priming by Rashid et al. (2004) and for sulfur by Sexton et al. (1998). Sulfur deficiency has been reported to decrease seed yield in the field by up to $20 \%$ (Sexton et al., 1998).
Emergence test showed that seed priming significantly increased emergence percentage (Table 2). Seed emergence of many species is stimulated by plant growth regulators and inhibited by salt stress (Sparks, 2005). These results are in agreement with Foti et al. (2008), who observed faster development, earlier flowering and maturity, and higher yields of maize under different seed priming types. Sedghi et al. (2008) demonstrated that priming with gibberelline increases the rate and percentage of seedling emergence in comparison with auxin in medicinal pumpkin (Cucurbita pepo). They concluded that gibberelline induces the production of the hydrolytic enzymes responsible for endosperm degradation, and causes faster germination. According to Tiryaki et al. (2004), cytokinin and ethylene secretion is stimulated by seed priming, and ethylene - or its precursor, 1-aminocyclopropane-1-carboxilic acid (ACC) - is the simplest unsaturated hydrocarbon that regulates diverse metabolic and developmental processes in plants, including seed germination.

No significant differences were observed in injury index among priming treatments (Table 2). Relative water and chlorophyll contents were greater in

Table 1. Mean emergence rate (MER) and grain yield of soybean submitted to four priming treatments and three sulfur $\left(\mathrm{K}_{2} \mathrm{SO}_{4}\right)$ application rates $\left(\mathrm{kg} \mathrm{ha}^{-1}\right)^{(1)}$.

\begin{tabular}{ccccc}
\hline $\begin{array}{l}\text { Sulfur } \\
\text { application rates }\end{array}$ & Nonprimed & $\begin{array}{c}\text { Water } \\
\text { priming }\end{array}$ & $\begin{array}{c}\text { Auxin } \\
\text { priming }\end{array}$ & $\begin{array}{c}\text { Gibberellin } \\
\text { priming }\end{array}$ \\
\hline \multicolumn{5}{c}{ Mean emergence rate $\left(\right.$ no. day $\left.{ }^{-1}\right)$} \\
0 & $1.2 \mathrm{~g}$ & $2.5 \mathrm{def}$ & $3.7 \mathrm{~cd}$ & $4.2 \mathrm{bc}$ \\
70 & $1.3 \mathrm{fg}$ & $3.0 \mathrm{cde}$ & $4.0 \mathrm{c}$ & $3.8 \mathrm{c}$ \\
140 & $1.8 \mathrm{efg}$ & $2.0 \mathrm{efg}$ & $5.5 \mathrm{a}$ & $5.3 \mathrm{ab}$ \\
\hline \multicolumn{5}{c}{ Grain yield $\left(\mathrm{kg} \mathrm{ha}^{-1}\right)$} \\
0 & $1,378.3 \mathrm{f}$ & $1,431.7 \mathrm{e}$ & $1,477.3 \mathrm{~d}$ & $1,480.7 \mathrm{~d}$ \\
70 & $1,540.0 \mathrm{c}$ & $1,576.7 \mathrm{ab}$ & $1,588.3 \mathrm{a}$ & $1,590.0 \mathrm{a}$ \\
140 & $1,551.7 \mathrm{bc}$ & $1,580.7 \mathrm{ab}$ & $1,588.7 \mathrm{a}$ & $1,590.7 \mathrm{a}$ \\
\hline (1) Means followed by equal letters within the evaluated variable do not \\
differ by Duncan's multiple range test, at $5 \%$ probability.
\end{tabular}

Table 2. Soybean studied traits at three different seed priming treatments and sulfur $\left(\mathrm{K}_{2} \mathrm{SO}_{4}\right)$ application rates $\left(\mathrm{kg} \text { ha }{ }^{-1}\right)^{(1)}$.

\begin{tabular}{|c|c|c|c|c|c|c|}
\hline $\begin{array}{l}\text { Priming } \\
\text { Treatments }\end{array}$ & $\begin{array}{c}\text { Emergence } \\
(\%)\end{array}$ & $\begin{array}{c}\text { Injury index } \\
(\%)\end{array}$ & $\begin{array}{c}\text { Relative water } \\
\text { content }(\%)\end{array}$ & $\begin{array}{l}\text { Chlorophyll Content } \\
\text { (SPAD index) }\end{array}$ & $\begin{array}{l}\text { Shoot length } \\
(\mathrm{cm})\end{array}$ & $\begin{array}{c}\text { Time of } \\
\text { maturity (days) }\end{array}$ \\
\hline Nonprimed & $63.60 \mathrm{~b}$ & $27.44 a$ & $74.55 b$ & $22.66 \mathrm{~b}$ & $28.22 b$ & $121.44 \mathrm{a}$ \\
\hline water & $85.77 \mathrm{a}$ & $26.44 \mathrm{a}$ & $76.33 \mathrm{ab}$ & $26.12 \mathrm{ab}$ & $32.55 \mathrm{a}$ & $105.33 b$ \\
\hline Auxin & $89.00 \mathrm{a}$ & $25.88 \mathrm{a}$ & $76.44 \mathrm{ab}$ & $30.02 \mathrm{a}$ & $34.00 \mathrm{a}$ & $105.22 b$ \\
\hline Gibberellin & $89.33 \mathrm{a}$ & $25.55 \mathrm{a}$ & $78.33 \mathrm{a}$ & $29.40 \mathrm{a}$ & $33.88 \mathrm{a}$ & $104.66 b$ \\
\hline \multicolumn{7}{|c|}{ Sulfur application rates } \\
\hline 0 & $81.08 \mathrm{a}$ & $33.83 \mathrm{a}$ & $64.83 c$ & $27.21 \mathrm{a}$ & $30.25 \mathrm{~b}$ & $107.91 \mathrm{a}$ \\
\hline 70 & $82.58 \mathrm{a}$ & $24.08 b$ & $80.02 b$ & $27.80 \mathrm{a}$ & $31.66 \mathrm{~b}$ & $110.16 \mathrm{a}$ \\
\hline 140 & $82.16 \mathrm{a}$ & $21.08 \mathrm{c}$ & $83.33 \mathrm{a}$ & $26.14 \mathrm{a}$ & $34.58 \mathrm{a}$ & $109.41 \mathrm{a}$ \\
\hline
\end{tabular}

${ }^{(1)}$ Means followed by equal letters do not differ by Duncan's multiple range test, at $5 \%$ probability. 
gibberellin primed plants than in non-primed plants. The overall growth (shoot length and time of maturity) in primed plants was higher than in non-primed plants. At 100 days after sowing, an 18\% increase in shoot length in primed plants was observed. Sulfur application showed no difference in the emergence percentage. Increasing the sulfur application rate decreased injury index in cell membrane and improved RWC. No significant differences in chlorophyll content and time of maturity were observed between the sulfur application treatments but shoot length was increased by $\mathrm{S}_{3}$ treatment.

\section{Conclusions}

1. On-farm seed priming improves emergence and early growth of soybean in fast drying and salty soils.

2. In general, priming treatments provide greater emergence rates and grain yields, and interact sinergically with sulfur application.

\section{References}

ALI, A.; MACHADO, V.S.; HAMILL, A.S. Osmoconditioning of tomato and onion seeds. Scientia Horticulturae, v.43, p.213-224, 1990 .

ANDERSON, J.W. Sulfur metabolism in plants. In: MIFIM, B.J.; LEA, P.J. (Ed.). The Biochemistry of plants. San Diego: Academic, 1990. p.327-381.

BEWLEY, J.D.; BLACK, M. Seeds: physiology of development and germination. New York: Plenum, 1994.

FOTI, R.; ABURENI, K.; TIGERE, A.; GOTOSA, J.; GERE, J. The efficacy of different seed priming osmotica on the establishment of maize (Zea mays L.) caryopses. Journal of Arid Environments, v.72, p.1127-1130, 2008.

HARRIS, D.; RAGHUWANSHI, B.S.; GANGWAR, J.S.; SINGH, S.C.; JOSHI, K.D.; RASHID, A.; HILLINGTON, P.A. Participatory evaluation by farmers of 'on-farm' seed priming in wheat in India, Nepal and Pakistan. Experimental Agriculture, v.37, p.403-415, 2001

ITANNA, F. Sulfur distribution in five Ethiopian Rift Valley soils under humid and semi-arid climate. Journal of Arid Environments, v.62, p.597-612, 2005.

KOCHEVA, K.; GEORGIEV, G. Evaluation of the reaction of two contrasting barley (Hordeum vulgare L.) cultivars in response to osmotic stress with PEG 6000. Bulgarian Journal of Plant Physiology, v.49, p.290-294, 2003.

MCDONALD, M.B. Seed priming. In: BLACK, M.; BEWLEY, J.D. (Ed). Seed technology and its biological basis. Sheffield: Sheffield Academic, 2000. p.287-325.
MCVEY, M.J.; PAUTSCH, G.R.; BAUMEL, C.P. Estimated domestic producer and end user benefits from genetically modifying U.S. soybeans. Journal of Production Agriculture, v.8, p.209-214, 1995.

PREMACHANDRA, G.S.; SANEOKA, H.; FUJITA, K.; OGATA, S. Leaf water relations, osmotic adjustment, cell membrane stability, epicuticular wax load and growth as affected by increasing water deficits in sorghum. Journal of Experimental Botany, v.43, p.1569-1576, 1992.

RASHID, A.; HARRIS, D.; HOLLINGTON, P.A.; RAFIQ, M. Improving the yield of mungbean (Vigna radiata) in the North West Frontier Province of Pakistan using on-farm seed priming. Experimental Agriculture, v.40, p.233-244, 2004.

SARDANS, J.; PEÑUELAS, J.; OGAYA, R. Drought's impact on $\mathrm{Ca}, \mathrm{Fe}, \mathrm{Mg}$, Mo and $\mathrm{S}$ concentration and accumulation patterns in the plants and soil of a Mediterranean evergreen Quercus ilex forest. Biogeochemistry, v.87, p.49-69, 2008.

SARDANS, J.; PEÑUELAS, J.; RODÀ, F. Plasticity of leaf morphological traits, leaf nutrient content, and water capture in the Mediterranean evergreen oak Quercus ilex subsp. ballota in response to fertilization and changes in competitive conditions. Ecoscience, v.13, p.258-270, 2006.

SAS INSTITUTE. SAS/STAT: user's guide. Version 7.0. Cary: SAS Institute, 1998.

SEDGHI, M.; GHOLIPOURI, A.; SEYED SHARIFI, R. Gamma-tocopherol accumulation and floral differentiation of medicinal pumpkin (Cucurbita pepo L.) in response to plant growth regulators. Notulae Botanicae Horti Agrobotanici Cluj-Napoca, v.36, p.80-84, 2008.

SEXTON, P.J.; PEAK, N.C.; SHIBLES, R. Soybean sulfur and nitrogen balance under varying levels of available sulfur. Crop Science, v.38, p.975-982, 1998.

SOEDA, Y.; KONINGS, M.C.J.M.; VORST, O.; VAN, A.M.M.L.; HOUWELINGEN, G.M.; STIIPEN, C.A.; MALIEPAARD, J.; KODDE, R.J.; BINO, S.P.C. Gene expression programs during Brassica oleracea seed maturation, osmopriming, and germination are indicators of progression of the germination process and the stress tolerance level. Plant Physiology, v.137, p.354-368, 2005.

SPARKS, D. L. Advances in agronomy. London: Elsevier Academic, 2005. 573p.

TIRYAKI, I.; KORKMAZ, A.; OZBAY, N.; NURI NAS, M. Priming in the presence of plant growth regulators hastens germination and seedling emergence of dormant Annual Ryegrass (Lolium multiflorum L.) seeds. Asian Journal of Plant Science, v.3, p.655-659, 2004.

TURNER, N.C. Techniques and experimental approaches for the measurement of plant water status. Plant and Soil, v.58, p.339-366, 1981.

WANG, H.Y.; CHEN, C.L.; SUNG, J.M. Both warm water soaking and solid priming treatments enhance anti-oxidation of bitter gourd seeds germinated at sub-optimal temperature. Seed Science and Technology, v.31, p.47-56, 2003.

WARTIDININGSIH, N.; GENEVE, R.L.; KESTER, S.T. Osmotic priming or chilling stratification improves seed germination of purple coneflower. Horticulture Science, v.29, p.1445-1448, 1994.

Received on February 13, 2009 and accepted on October 10, 2009 